\title{
Rice Selling Vs. Grain Selling Farms: Which One is More Profitable?
}

\author{
By: \\ Adi Nurfadilah Rosyandi ${ }^{11}$, Supadi ${ }^{2)}$, Kikin Windhani ${ }^{3)}$ \\ ${ }^{1)}$ Faculty of Economics and Business, Universitas Jenderal Soedirman \\ ${ }^{1)}$ Email: fadilahnr@gmail.com
}

\begin{abstract}
The objectives of this study were to compare the income and efficiency between grain selling farmers and rice selling farmers, and analyzed added value. Population in this study were all rice farmers in Kapandayan Village. With proportionate random sampling, 34 grain selling farmers and 16 rice selling farmers were selected as respondents. The data were analyzed with income analysis, independent samples t-test, Hayami's method and $\mathrm{R} / \mathrm{C}$ ratio. The results indicated that rice selling farmers had a higher income than grain selling farmers, the result of $t$ test indicated that there was a significant difference. Hayami's method indicated that there was a positive added value of $\mathrm{Rp} 786 / \mathrm{kg}$, from which the farmers received $86 \%$ of total added value, and the remaining $14 \%$ was received by direct labor. $\mathrm{R} / \mathrm{C}$ ratio of grain selling farmers was 1.57 and $\mathrm{R} / \mathrm{C}$ ratio of rice selling farmers was 1.68 . The analysis result of $\mathrm{R} / \mathrm{C}$ ratio indicated that rice farmers in Kapandayan Village have been efficient.
\end{abstract}

Keywords: Farmer, Income, Value Added, Efficiency.

\begin{abstract}
ABSTRAK
Tujuan dari penelitian ini adalah untuk membandingkan pendapatan dan efisiensi petani penjual gabah dan petani penjual beras dan menganalisis nilai tambah. Populasi dalam penelitian ini adalah seluruh petani padi di desa Kapandayan. Sampel dalam penelitian ini ditentukan menggunakan proportionate random sampling. Sampel dalam penelitian terdiri dari 34 petani yang menjual gabahdan 16 petani yang menjual beras. Data penelitian dianalisis menggunakan analisis pendapatan, independent sample t-test, metode Hayami dan $R / C$ ratio. Hasil dari penelitian menunjukkan bahwa petani yang menjual beras memiliki pendapatan lebih tinggi daripada petani yang menjual gabah dan hasil uji $t$ menunjukan bahwa terdapat perbedaan yang signifikan. Kemudian, metode Hayami menunjukkan bahwa ada nilai tambah positif sebesar Rp786 / kg, di mana $86 \%$ dari nilai tambah diterima oleh petani dan $14 \%$ diterima oleh tenaga kerja langsung. $R / C$ ratio dari petani yang menjual Gabah adalah 1,57 dan $R / C$ ratio dari petani yang menjual beras adalah 1,68 . Hasil analisis $R / C$ ratio menunjukkan bahwa petani padi di Desa Kapandayan sudah efisien.
\end{abstract}

Kata Kunci: Petani, Pendapatan, NilaiTambah, Efisiensi.

\section{INTRODUCTION}

Agriculture is one of the most important things in national development, in addition to fulfilling food needs, the agricultural sector is also a sector that provides employment in Indonesia (Supartini \& Karyati, 2012). As an agricultural country, Indonesia has 36.7 million hectares of agricultural land. most of Indonesian population work as farmers. It can be seen in thelabor absorption in the agricultural sector by 29.86 percent of the total labor in Indonesia (Central Bureau of Statistics, 2017). This figure is the highest among other sectors, this is a natural thing. 
The agricultural sector is an important sector in contributing to the welfare of the Indonesian population. The contribution of the agricultural sector to welfare has fluctuated annually (Agustono, 2013) but the agricultural sector contribution to the was the highest after the industrial sector and the trade sector by 13.14 percent to real GDP in 2017 (Central Bureau of Statistics, 2017), however, the contribution of the agricultural sector to economic growth has fluctuated. However, economic activities initially engaged in agriculture began to shift to other sectors such as industry, so that currently the agricultural sector has been left because many people assume that agriculture does not provide prosperity, as seen from the contribution of the agricultural sector to the number of poor people by 33.3\% of the total poor population in 2016 (Statistics of Poverty in the Agricultural Sector, 2017).

This was partly due to the large number of parties involved from the production process to the process of selling agricultural products such as middlemen. After harvesting, the majority of farmers directly sold their unhulled rice to middlemen in the area of harvest. This also occurred in Kapandayan Village, Ciawigebang Sub-district, Kuningan Regency, where the labor absorption was more than $30 \%$. The data shows that agriculture is the main sector of the economy of the Kapandayan Village community, so it should benefit the community. However, on the contrary, many farmers prefer to sell their crops in the form of grain to middlemen, even though this sale has a number of problems, namely the amount of yields piled up, while the sales are limited, so prices will be low (Mudakir, 2007).

However, some farmers in Kapandayan Village sold their crops in the form of rice, so that the price received was higher and the sales were not limited to middlemen. The increasing prices of grain and rice since the reign of President Soeharto became a problem for the rice economy. This condition wasused by middlemen to monopolize prices at the farmer level. It can be seen that the market price for grain in Kapandayan village was $\mathrm{Rp} \mathrm{4,700} \mathrm{/} \mathrm{kg}$ - Rp 5,200 / kg, while the market price for rice was $\mathrm{Rp} \mathrm{9,000/} \mathrm{Kg} \mathrm{-} \mathrm{Rp} \mathrm{9,500} \mathrm{/} \mathrm{kg.} \mathrm{Thus,} \mathrm{there} \mathrm{was} \mathrm{a} \mathrm{significant} \mathrm{difference} \mathrm{in} \mathrm{prices} \mathrm{received} \mathrm{by} \mathrm{grain}$ selling farmers and rice selling farmers.

This difference in selling prices should encourage farmers to prefer to sell rice due to its higher price. However, based on the preliminary study in Kapandayan Village, it was found that out of 102 farmers, 70 farmers sold the crops in the form of grain and 32 farmers sold the crops in the form of rice.

\section{METHODS}

Population in this study was all rice farmers in Kapandayan Village consisting of 102 farmers. With proportionate random sampling method (Gudjarati,2009), 34 grain selling respondents and 16 rice selling respondents were selected. This study was conducted in November 2018. Data collection technique was survey method. In this method, information was collected from respondents using a questionnaire as a primary data collection tool.

Data analysis techniques used in this study were income analysis, $\mathrm{R} / \mathrm{C}$ ratio and t test. Income analysis is calculated by the following formula (Soekartawi, 2002; Popidylah \& Suyatno, 2009):

$$
\pi=T R-T C
$$

Where:

$\pi=$ Net income offarming (Rp)

$T R \quad=$ Total revenue of farming (production value) (Rp)

$T C=$ Total cost of farming (Rp)

$\mathrm{R} / \mathrm{C}$ ratio analysis is calculated as follows (Soekartawi, 2002):

$$
R / C=\frac{P \cdot Q}{T V C+T F C}
$$


Where:

$$
\begin{array}{ll}
R & =\text { Total revenue }(\mathrm{Rp}) \\
C & =\text { Total cost }(\mathrm{Rp}) \\
P & =\text { Price }(\mathrm{Rp}) \\
Q \quad & =\text { Quantity }(\mathrm{Kg}) \\
T V C & =\text { Total variable cost }(\mathrm{Rp}) \\
T F C & =\text { Total fixed cost }(\mathrm{Rp})
\end{array}
$$

\section{Decision criteria:}

$\mathrm{R} / \mathrm{C}>1$, farming is profitable (efficient)

$\mathrm{R} / \mathrm{C}<1$, farming suffers a loss (inefficient)

$\mathrm{R} / \mathrm{C}=1$, farming is break-even (neither profit nor loss)

Hayami's value added method was used to analyze value added. Table 1 shows the framework of calculation of Hayami's value added method.

Table 1. Framework of Calculation of Hayami's Value Added Method

\begin{tabular}{clc}
\hline No. & Output, Input, Price & Formula \\
\hline 1 & Production (kg) & $\mathrm{A}$ \\
2 & Raw material (kg) & $\mathrm{B}$ \\
3 & Labor (Man-Day) & $\mathrm{C}$ \\
4 & Conversion factor & $\mathrm{A} / \mathrm{B}=\mathrm{M}$ \\
5 & Coefficient of labor & $\mathrm{C} / \mathrm{B}=\mathrm{N}$ \\
6 & Production price (Rp / kg) & $\mathrm{D}$ \\
7 & Average wage (Rp) & $\mathrm{E}$ \\
\hline & Income & $\mathrm{F}$ \\
\hline 8 & Price of raw material (Rp / kg) & $\mathrm{G}$ \\
9 & Additional material (Rp / kg) & $\mathrm{K}=\mathrm{M} \times \mathrm{D}$ \\
10 & Product value (Rp / kg) & $\mathrm{L}=\mathrm{K}-\mathrm{F}-\mathrm{G}$ \\
11 & a. Value added (Rp / kg) & $\mathrm{H}=(\mathrm{L} / \mathrm{K})$ \\
& b. Value added ratio (\%) & $\mathrm{P}=\mathrm{N} \times \mathrm{E}$ \\
12 & a. Wage of direct labor (Rp / kg) & $\mathrm{Q}=(\mathrm{P} / \mathrm{L})$ \\
& b. Share of direct labor (\%) & $\mathrm{R}=\mathrm{L}-\mathrm{P}$ \\
13 & a. Profit (Rp / kg) & $\mathrm{I}=(\mathrm{R} / \mathrm{L})$ \\
& b. Profit rate (\%) & \\
\hline & Remuneration for Production Factors & $\mathrm{S}=\mathrm{K}-\mathrm{F}$ \\
\hline 14 & Margin (Rp / kg) & $\mathrm{T}=(\mathrm{P} / \mathrm{S})$ \\
& a. Income of direct labor (\%) & $\mathrm{U}=(\mathrm{G} / \mathrm{S})$ \\
& b. Contribution of other input (\%) & $\mathrm{V}=(\mathrm{R} / \mathrm{S})$ \\
\hline & C Employer Profit (\%) & \\
\hline
\end{tabular}

Source: Sudiyono, 2004

Independent samples $\mathrm{t}$ test is calculated by the following formula (Sugiyono, 2010):

$$
\left(t_{\text {table }} \text { seen from } d k=n_{1}-n_{2}-2\right)
$$

$$
t=\frac{\bar{x}_{2}-\bar{x}_{1}}{\sqrt{\frac{\left(n_{1}-1\right) S_{1}^{2}+\left(n_{2}-1\right) S_{2}^{2}}{n_{1}-n_{2}-2}\left(\frac{1}{n_{1}}+\frac{1}{n_{2}}\right)}}
$$


Where:

$\bar{x}_{1}=$ Average income of grain selling farmers (per hectare)

$\bar{x}_{2}=$ Average income of rice selling farmers (per hectare)

$S_{1}^{2} \quad$ = Sample variance of grain selling farmers

$S_{2}^{2}=$ Sample variance of rice selling farmers

$n_{1} \quad$ = Sample size of grain selling farmers

$n_{2} \quad$ = Sample size of rice selling farmers

$D k$ = Degree of freedom

The conclusion of the test is drawn by comparing between $\mathrm{t}$ statistic and $\mathrm{t}$ table:

a. $t_{\text {statistic }} \geq t_{\text {table }}, \alpha 0.05$, then $H_{0}$ is accepted and $H_{1}$ is rejected.

b. $t_{\text {statistic }}<t_{\text {table }}, \alpha 0.05$, then $H_{0}$ is rejected and $H_{1}$ is accepted.

\section{RESULTS AND DISCUSSIONS}

Production is a process of generating output by utilizing production factors (Suparmoko, 2013). In this study, there were two patterns of selling, namely farmers selling their crops in the form of grain and those selling their crops in the form of rice. In Kapandayan Village, rice farming usually takes 100 days. In the process, rice farmers in the Kapandayan Village have been using technologies such as field plowing tractor. However, the rice farmers do not use machinery for other processes such as applying fertilizers and pesticide and harvesting, but only use traditional tools such as pump sprays for fertilizers and pesticides and harvest machetes. After the harvest period, thegrain selling farmers did not store the crops, but sold the grain directly to the middlemen in the area of harvest, while the rice selling farmers brought the crops to the mill before selling it.

\section{Analysis of Rice Farming Income}

Income is the sales received by farmers minus production costs (Soekartawi, 2002). Production cost is the overall costs borne by the farmer in one planting period or 100 days. Production cost in this study consists of fixed costs and variable costs. Fixed cost includes land rent cost and depreciation cost, while variable cost includes labor cost, seed cost, fertilizer cost and pesticide cost.

Table 2. Average Income in Farming per Hectare per Planting Season

\begin{tabular}{lrrrr}
\hline \multirow{2}{*}{ Description } & \multicolumn{2}{c}{ Grain Selling Farmer } & \multicolumn{2}{c}{ Rice Selling Farmer } \\
\cline { 2 - 5 } & Per hectare & $\%$ & Per hectare & $\%$ \\
\hline Land rent (Rp) & $2,199,167$ & - & $2,330,011$ & - \\
Depreciation (Rp) & 56,695 & - & 40,901 & - \\
\hline Fixed cost (Rp) & $2,255,862$ & $15 \%$ & $2,370,912$ & $14 \%$ \\
\hline Labor (Rp) & $10,942,610$ & - & 12.572 .598 & - \\
Seed (Rp) & 464,633 & - & 509,309 & - \\
Fertilizer (Rp) & $1,390,929$ & - & $1,303,723$ & - \\
Pesticide (Rp) & 168,929 & - & 124,335 & - \\
\hline Variable cost (Rp) & $12,967,101$ & $85 \%$ & $14,490,833$ & $86 \%$ \\
\hline Total cost (Rp) & $15,222,963$ & $100 \%$ & $16,861,745$ & $100 \%$ \\
\hline Production (kg) & 4,791 & - & 3,007 & - \\
Price (Rp / kg) & 4,944 & - & 9,431 & - \\
\hline Total Revenue (Rp) & $23,869,485$ & - & $28,399,954$ & - \\
\hline$\pi(\mathrm{Rp})$ & $8,646,522$ & - & $11,538,209$ & - \\
\hline
\end{tabular}

It can be seen in Table 2 that there are differences in total cost between grain selling farmers and rice selling farmers, the significant difference in costs can be seen on variable cost of Rp1,629,988. This is attributed to a longer process for rice sellers as the farmers need to mill the 
grain to produce rice and transport rice in the post-harvest process. Therefore, the average total cost incurred by therice selling farmers is $10.7 \%$ higher than thegrain selling farmers with a difference of Rp1,638,782.

Each farmer earns different income, the average selling price of grain product is Rp4,944/kg and average selling price of rice product is $\mathrm{Rp} 9,431 / \mathrm{kg}$. Meanwhile, the average production for 1 hectare of land is 4,791 kg of grain and 3,007 kg of rice. Rice production is carried out by milling the grain. In Kapandayan village, it was found that the average conversion from grain to rice was $63.43 \%$, meaning that any farmer milling $100 \mathrm{~kg}$ of grain will obtain $63.43 \mathrm{~kg}$ of rice. With a different selling price between grain and rice, the income of rice selling farmerswas $18.9 \%$ higher than grain selling farmers, the difference wasRp4,530,469.

The analysis result of independent samples $t$ test between the income of grain selling farmers and rice selling farmers per hectare can be seen at Table 3 .

Table 3. Analysis of Independent Sample t Test per Hectare

\begin{tabular}{llccccc}
\hline \multirow{2}{*}{ No. Description } & \multicolumn{5}{c}{ Independent Sample t Test } \\
\cline { 2 - 5 } & & Mean & Std. Deviation & $t$ & $\mathrm{df}$ & Sig. \\
\hline 1 & Rice selling farmer & $11,538,209$ & $2,047,633$ & 4.289 & 48 & 0.000 \\
2 & Grain selling farmer & $8,646,522$ & $3,423,438$ & & & \\
\hline
\end{tabular}
Source: Primary Data, 2018 (Processed)

From Table 3, it can be seen that the significance value of the independent samples $t$ test is 0.000. Therefore, it can be concluded that $H_{0}$ is rejected and $H_{1}$ is accepted. This means that the income of rice selling farmers per hectare per planting season is higher than that of grain selling farmers per hectare per planting season.

\section{Analysis of Value Added}

Table 4. Value Added of Rice Production in Kapandayan Village in 2018

\begin{tabular}{clcc}
\hline No. & Output, Input, Price & Formula & Value \\
\hline 1 & Rice (kg / hectare) & $\mathrm{A}$ & 3,007 \\
2 & Grain (kg / hectare) & $\mathrm{B}$ & 4,742 \\
3 & Labor (working day) & $\mathrm{C}$ & 4 \\
4 & Conversion factor & $\mathrm{A} / \mathrm{B}=\mathrm{M}$ & 0.6341 \\
5 & Coefficient of labor & $\mathrm{C} / \mathrm{B}=\mathrm{N}$ & 0.0008 \\
6 & Price of rice (Rp / kg) & $\mathrm{D}$ & 9,431 \\
7 & Average labor cost (Rp / hectare) & $\mathrm{E}$ & 135,000 \\
\hline & Income & $\mathrm{F}$ & \\
\hline 8 & Price of grain (Rp / kg) & $\mathrm{G}$ & 4,845 \\
9 & Other input (Rp / kg) & $\mathrm{K}=\mathrm{M} \times \mathrm{D}$ & 349 \\
10 & Value of rice (Rp / kg) & $\mathrm{L}=\mathrm{K}-\mathrm{F}-\mathrm{G}$ & 5,980 \\
11 & a. Added value (Rp / kg) & $\mathrm{H}=(\mathrm{L} / \mathrm{K})$ & 786 \\
& b. Added value ratio (\%) & $\mathrm{P}=\mathrm{N} \times \mathrm{E}$ & $13 \%$ \\
12 & a. Remuneration of direct labor (Rp / kg) & $\mathrm{Q}=(\mathrm{P} / \mathrm{L})$ & 114 \\
& b. Share of direct labor (\%) & $\mathrm{R}=\mathrm{L}-\mathrm{P}$ & $14 \%$ \\
13 & a. Profit (Rp / kg) & $\mathrm{I}=(\mathrm{R} / \mathrm{L})$ & 673 \\
& b. Profit rate (\%) & & $86 \%$ \\
\hline & Remuneration of Production Factors & $\mathrm{S}=\mathrm{K}-\mathrm{F}$ & \\
\hline 14 & Margin (Rp/kg) & $\mathrm{T}=(\mathrm{P} / \mathrm{S})$ & 1,135 \\
& a. Income of direct labor (\%) & $\mathrm{U}=(\mathrm{G} / \mathrm{S})$ & $10 \%$ \\
& b. Contribution of other (\%) & $\mathrm{V}=(\mathrm{R} / \mathrm{S})$ & $31 \%$ \\
& c. Farmer's profit (\%) & $59 \%$ \\
\hline
\end{tabular}

Source: Primary Data, 2018 (Processed) 
Value added is a value added for a commodity obtained due to changes in form, transportation, storage or due to ownership. In this study,Hayami's method was used to examine value added. This method was used to calculate the valueadded obtained from processing grain into rice as can be seen at Table 4 .

Based on Table 4, it can be explained that the processing from grain into rice is as follows:

\section{Output, Input, and Price}

Grain is raw material in rice production. This study found that the average grain production was $4.742 \mathrm{~kg} / \mathrm{hectare}$. After being processed by milling grain, it produced rice of $3,007 \mathrm{~kg} / \mathrm{hectare}$. Conversion value from grain into rice was $63.43 \%$. This indicated that $100 \mathrm{~kg}$ of grain produced 63.43 $\mathrm{kg}$ of rice. The processing took 1 working day with 4 labor, consisting of 3 persons as factory workers and 1 person for transporting rice. The average labor cost spent on 1 hectare of land was Rp135,000 / person.

\section{Income}

The raw material for processing rice is grain. The average selling price of grain was $\mathrm{Rp} 4,845.00 / \mathrm{kg}$ and other input cost, namely the cost of milling at the factory was Rp 349/kg. From Table 4, it can be seen that the average value of rice product is not the same as the average selling price because the value of the product is derived from the value addedobtained from the conversion from grain to rice. The value of rice product is $\mathrm{Rp} 5,980 / \mathrm{kg}$. The value added can be obtained from the calculation of rice product value of $\mathrm{Rp} 5,980$ minus the average selling price of grain of $\mathrm{Rp} 4,845 / \mathrm{kg}$ and other input cost, namely the cost of milling at the factory of Rp349/ $\mathrm{kg}$ equal to Rp786 $\mathrm{kg}$ or $13 \%$ of rice product value.

The farmers did not obtain all the generated valueadded, some were distributed to other party, namely direct labor. From Table 4, the direct labor received a remuneration of Rp114.00 or $10 \%$ of the total value added, while farmers earn a profit of Rp673.00 or $86 \%$ of the total value added. Thus, the farmers processing $1 \mathrm{~kg}$ of grain into rice received an additional income of Rp673.00.

\section{Remuneration of Production Factors}

At Table 4, it can be seen that margin is product value minus raw material, where the margin obtained is Rp1,135.00. From the margin, direct labor earns income of $10 \%$ of the margin, the mill earns $31 \%$ of the margin, while farmers earn profit of $59 \%$ of the margin.

\section{Analysis of Economic Efficiency (R/C Ratio)}

Efficiency is the ability of farming to manage its business by processing input and output appropriately. Efficiency analysis is carried out by comparing the average revenue with the average cost or commonly called as R/C ratio. In this study, there were 2 sales patterns in farming, so that efficiency analysis was carried out for each pattern. The results of efficiency analysis can be seen at Table 5.

Table 5. Comparative Analysis of R/C Ratio

\begin{tabular}{|c|c|c|c|}
\hline \multicolumn{2}{|c|}{ No. lescription } & \multirow{2}{*}{$\frac{\text { Grain Seller }}{15,222,963}$} & \multirow{2}{*}{$\begin{array}{c}\text { Rice Seller } \\
16,861,745\end{array}$} \\
\hline 1 & Total cost (Rp) & & \\
\hline 2 & Total revenue (Rp) & $23,869,485$ & $28,399,954$ \\
\hline \multicolumn{2}{|r|}{$\mathrm{R} / \mathrm{C}$ ratio $(\mathrm{Rp})$} & 1.57 & 1.68 \\
\hline
\end{tabular}

Table 5 shows that $R / C$ ratio for rice sellingfarmers is higher than grain sellingfarmers by 0.11 . It can be seen that $\mathrm{R} / \mathrm{C}$ ratio for grain sellingfarmers is 1.57 , meaning that any increase in cost of Rp1,000.00 will increase revenue by Rp1,570.00. While R/C ratio for rice sellingfarmers is 1.68 , meaning that any increase in cost of $\mathrm{Rp} 1,000$ will increase revenue by $\mathrm{Rp} 1,680$. Based on the analysis 
result of $R / C$ ratio, both grain and rice selling farmers have been economically efficient because they had $\mathrm{R} / \mathrm{C}$ ratio greater than $1(\mathrm{R} / \mathrm{C}>1)$.

\section{CONCLUSIONS}

Based on the analysis of this study, both grain and rice selling farmers earned profit from rice farming. The grain selling farmers earned Rp8,646,522/hectare and the rice selling farmers $\mathrm{Rp} 11,538,209 /$ hectare. The income of the rice selling farmers was $33.4 \%$ higher than that of the grain selling farmers.

From the calculation of value added using Hayami's method, it was found that there was a positive valueaddedof $\mathrm{Rp} 786 / \mathrm{kg}$ if the farmers sell rice. From the total value added generated, the farmers received $86 \%$ of the total value addedor Rp673/ $\mathrm{kg}$ and the remaining $14 \%$ or Rp114/ $\mathrm{kg}$ was received by direct labor. Thus, if the farmers process $1 \mathrm{~kg}$ of grain into rice, they will earn additional income of Rp.673.

Efficiency values of the grain selling farmers and rice selling farmers were 1.57 and 1.68 , respectively. These values were greater than $1(R / C>1)$, meaning that both grain and rice selling farmers have been efficient. The efficiency of rice selling farmers was higher than that of the grain selling farmers $(1.68>1.57)$.

In this study, it was found that rice farming in Kapandayan village both by selling grain and selling rice was profitable to the farmers. Therefore, the farmers in Kapandayan Village should continue to carry out rice farming. From the two sales patterns, it was found that the rice selling farmers had a good prospect to be implemented in Kapandayan Village because the rice selling farmers had a higher income of $33.4 \%$ compared to the grain selling farmers. In addition, rice sales did not harm the farmers as rice can be sold directly to consumers, so that it can reduce farmers' dependence on middlemen. This can be a way to increase income and welfare of farmers in Kapandayan Village.

By using Hayami's method, it was found that $86 \%$ of value added from the sales of rice was received directly by the farmers, so that it will be better if the grain selling farmers begin sell rice. If the farmers process $1 \mathrm{~kg}$ of grain into rice, they will receive additional income of Rp711 or there was an increase in income of $14 \%$ higher than the income when they sell grain.

Although the result of analysis indicated that the grain selling farmers and the rice selling farmers have been economically efficient $(R>1)$, there is an opportunity for the farmers in Kapandayan Village to improve their efficiency as several costs can be reduced, especially labor cost for fertilizing and harvesting. In this study, it was found that labor cost contributed $71.8 \%$ of total cost of grain-selling farms and $74.5 \%$ of total cost of rice-selling farms. Currently, there are technologies to facilitate and accelerate the production process, such as harvesting machine to speed up the harvest process. Therefore, the use of the latest technologies can reduce labor cost and can improve efficiency.

\section{REFERENCES}

Agustono. (2013). Analysis of agricultural sector viewed from the role of growth and stability of gross regional domestic products in Central Java Province. SEPA, 9(2), 283-296.

Central Bureau of Statistics of West Java Province. (2017). Condition of work force in West Java Province. Central Statistics Agency. Bandung, Indonesia: Central Bureau of Statistics of West Java Province.

Central Bureau of Statistics of West Java Province. (2018). West Java Province in figures 2018. Bandung, Indonesia: Central Bureau of Statistics of West Java Province.

Ministry of Agriculture of the Republic of Indonesia. (2017). 2017 agricultural statistics. Jakarta, Indonesia: Center for Agricultural Information Data and System of Ministry of Agriculture of the Republic of Indonesia.

Mudakir, B. (2007). Analysis of rice paddy farming in Central Java. Economic Focus, 6(1), 18-35 
Popidylah, R. \& Suyatno. (2015). Analysis of income of rice farming in Sungai Kinjil Village, Benua Kayong District, Ketapang Regency. Journal of Social Economic of Agriculture, 4(2), 74-87.

Soekartawi. (2002). Farming analysis. Jakarta, Indonesia. University of Indonesia Press.

Sudiyono, A. (2004). Agricultural marketing. Malang, Indonesia: Muhammadiyah University of Malang Press.

Suparmoko, M. (2013). Microeconomic theory. Yogyakarta, Indonesia: BPPE.

Supartini, M. \& Karyati. (2012). Comparative Analysis of income of organic rice and inorganic rice farming. Dwijen AGRO, 5(2). 